Bol. Acad. peru. leng. 53. 2012 (133-136)

\title{
LA NOVELA COMO ESTRIPTÍS INVERTIDO
}

\author{
Pedro Luis Barcia \\ Academia Argentina de Letras
}

Fecha de recepción: $\quad$ 26/04/2012

Fecha de aceptación: $\quad$ 05/06/2012

Vargas Llosa estima, en Historia secreta de una novela (1971), referida a $L a$ Casa Verde, que "Escribir una novela es una ceremonia de strip tease invertido". Comienza la tarea del narrador con la exposición desnuda de las penas y nostalgias, los sueños y las experiencias del autor, las obsesiones y fantasmas que lo atenazan, y, a partir de ellas, se inicia el arropamiento gradual de esa materia íntima mediante palabras, que la van envolviendo, colocando sus capas superpuestas sobre esa realidad desnuda primera hasta cubrirla por completo. Concluida la elaboración de la novela, lo expósito original que la motivó queda embozado, disfrazado e irreconocible. El proceso que el ensayo muestra es ese encubrimiento o velación de la materia vital primitiva por medio de un proceso de poética encubridora, cumplido, en el caso de La Casa Verde, entre 1962 y 1965. Esta realidad planteada es la que se cumple, al menos, en la mayoría de las novelas del autor, radicadas en su Perú natal que le ha dado su espacio a todas sus ficciones, salvo La guerra del fin del mundo (situada en Brasil, en el siglo XIX) y La fiesta del chivo (República Dominicana). Las 
experiencias vividas generaron La ciudad y los perros, La Casa Verde, Conversación en La Catedral, Pantaleón y las visitadoras y La tía Julia y el escribidor. Sin embargo, aunque nacidas de la realidad experiencial y radicadas en sitios reconocibles y ciertos, no estamos frente a una narrativa elementalmente realista. Sus ficciones contienen, cierto, denuncias sociales y políticas, señalamientos de las formas de la corrupción, del despotismo... Pero las estética y técnicas desde las que trata su materia no son del realismo tradicional, que Borges señalaba "como una invención tardía del siglo XIX", y que para tantos agota reductivamente la literatura, y empobrece otras dimensiones de la creación estética.

Uno de los rasgos identitarios de la narrativa del flamante Premio Nobel es su probada capacidad para relacionar al personaje con su medio, sea institucional (liceo, ciudad), o natural (la selva) y proponer, esto es ponernos por delante, la lucha del individuo con los órdenes sacralizados de las instituciones, de la sociedad o de los gobiernos totalitarios que lo amenazan y afectan en su libertad. Porque el eje de su visión del mundo es la milicia del hombre libre contra las estructuras condicionantes. Es la misma pulsión que lo llevó a desprenderse de sus juveniles posturas comunistas y abrazar la causa de las libertades individuales. Quien supo apoyar la revolución cubana en su inicio, también supo distanciarse y convertirse en un crítico firme al desvirtuarse en ella todas las libertades. Se sabe, la evolución en este sentido no es perdonada por quienes perduran en el otro extremo, en el de la preferencia del Estado por sobre el hombre.

El novelista, según lo afirma Vargas Llosa, es un deicida: mata a Dios para reemplazarlo en su poder creativo. Ya decía Mauriac que «el novelista es el mono de Dios», haciendo, muy a lo francés, un giro no declarado, de la frase, sabida por los teólogos, con que san Agustin denominaba al demonio: simio Dei. Dante apuntaba que el arte es nieto de Dios, y Balzac postulaba que el novelista compite con la cuota de nacimientos y defunciones de sus criaturas de papel, con el Registro Civil. Historia de un deicidio (1971) fue el título que le dio al impar estudio sobre la obra de García Márquez, en el sentido intencional apuntado. 
De los hombres del boom inicial (dejemos lo de posboom, posposboom, y demás), Vargas Llosa es el que aúna de manera más profesional, es decir, con lúcida fundamentación teórico-estética, el manejo de los más diversos recurso técnicos. En callida iunctura articula los más complejos planos de la ficción (recuérdese, p.ej., Conversación...) y la materia narrable; su despliegue de recursos y procedimientos experimentales y renovadores están, amaestradamente, puestos al servicio de la eficacia fabuladora con baquía infrecuente. En otros coetáneos, el exceso de tecnolotría queda tan a la vista que denuncia la impericia del narrador. En él, las técnicas, bien avenidas con sus propósitos, logran invisibilidad. Este ideal se da en sus relatos.

Es recordable lo que ocurrió en aquel diálogo con García Márquez en la Universidad de San Marcos. Entusiasmado con el análisis de la obra de su colega, avanzaba en la dilucidación de las raíces personales de la mitificación y en las formas de tratamiento hipertrofiado de la materia narrada, cuando Gabo lo interrumpió pidiéndole que no explore más en esa dirección reveladora, porque «le mataría sus demonios». Es decir, lo haría hiperconsciente de las fuerzas oscuras que animaban en su espíritu y las técnicas que naturalmente manejaba para la poiesis, pues, al identificarlas con sus nombres propios, casi como en el psicoanálisis, aventaría los fantasmas, pero moriría a la creación sin ellos.

Vargas Llosa ha titulado a un conjunto de sus notables ensayos sobre la novela moderna La verdad de las mentiras (1990). El título es toda una definición: las ficciones instalan frente al lector su realidad que resulta tan reveladora sobre la índole del hombre y del mundo, que insta a la aceptabilidad de la ficción. Se trata de una vuelta de tuerca a la manida frase de Coleridge: «la suspensión voluntaria de la incredulidad».

El autor es un notable testigo ocular, para usar la expresión de Hillaire Belloc, de la realidad cotidiana. Frente a ella, casi diariamente, juega opinión, interpreta, valora, critica. Allí están sus varios tomos colectores de una obra ensayística, en gran medida 
difundida por vía periodística. Los artículos sabáticos suyos, en la plana de este diario, lo prueban, y los muchos difundidos en varios idiomas por el universo mundo.

«La democracia y la felicidad no producen gran literatura», escribió; si la generan los déspotas políticos. Allí está la vasta galería que construyeron Asturias, García Márquez, Roa Bastos, y un largo etcétera. Y los déspotas que aún esperan a su novelista de turno.

Vargas Llosa escribió: «Las amenazas a la democracia en América Latina son el terrorismo, la debilidad del estado de derecho y el neopopulismo»; elijamos el sayo que nos corresponda.

\section{Correspondencia:}

\section{Pedro Luis Barcia}

Presidente de la Academia Argentina de Letras

Correo electrónico: secretaria.aal@fibertel.com.ar 